\title{
What Do We (Not) Know About the Human Bartonelloses?
}

Paulo Eduardo Neves Ferreira Velho, Maria Letícia Cintra,Ana Maria Uthida-Tanaka, Aparecida Machado de Moraes, and Andréia Mariotto
Department of Internal Medicine and Department of Pathological Anatomy, Medical School Sciences, State University of Campinas-FCM/Unicamp, São Paulo, Brazil

The human bartonelloses are a group of diseases with a rapidly increasing clinical spectrum. Well known manifestations such as Carrion's disease, trench fever, cat-scratch disease, and bacillary angiomatosis are examples of Bartonella spp. infection. Along with these diseases, recurrent bacteremia, endocarditis, septicemia, erythema nodosum, erythema multiforme, trombocytopenic purpura and other syndromes have been reported having been caused by bacteria of this genus. The infectious process and the pathogenesis of these microorganisms are poorly understood. The bartonelloses may have a benign and self-limited evolution in a host, or a potentially fatal one. These bacteria can provoke a granulomatous or an angioproliferative histopathologic response. As these diseases are not yet well defined, we have reviewed the four main human bartonelloses and have examined unclear points about these emergent diseases.

Key Words: Bartonella, Carrion's disease, trench fever, cat-scratch disease, bacillary angiomatosis.

The bartonellas are considered to be emergent infectious agents [1,2]. After the reclassification proposed by Brenner et al, 1993, B. bacilliformis was no longer considered the only bacterium of this genus and Carrion's disease was no longer the only human bartonellosis [3]. After the inclusion of Rochalimeae spp., as they were then called, human diseases caused by bartonellas included trench fever, cat scratch disease, and bacillary angiomatosis [4-7].

The clinical spectrum of Bartonella infection has increased with the increasing number of studies concerning this genus. Besides the aforementioned diseases, we now know that the bartonellas can cause recurrent bacteremia, endocarditis, and septicemias, and are the cause of syndromes such as

Received on 03 May 2002; revised 11 November 2002.

Address for correspondence: Dr. Paulo Velho. Department of Internal Medicine, Medical School Sciences, State University of Campinas - FCM/Unicamp. Cidade Universitária Zeferino Vaz, s/n, 13.081-970, Campinas, SP, Brazil.

Phone/Fax:55-19-3289-4107.E-mail:pvelho@obelix.unicamp.br

The Brazilian Journal of Infectious Diseases 2003;7(1):1-6 (C) 2003 by The Brazilian Journal of Infectious Diseases and Contexto Publishing. All rights reserved. thrombocytopenic purpura, erythema multiforme, erythema nodosum, exanthemas, chronic adenopathy, and chronic fatigue syndrome. Osteolytic lesions, neurological and even psychiatric manifestations have also been associated with infections by these agents [8]. Some of these manifestations may be fatal, especially in immunodeficient patients [9].

Bartonella spp. are Gram-negative bacilli or coccobacilli; small and delicate, that grow fastidiously. They require enriched blood mediums, with high levels of $\mathrm{CO}_{2}$. That is why they are rarely cultivated routinely in most microbiology labs, and bacterial culture of blood or tissue samples is not the best diagnostic method for detection of these agents [2,7,10,11]. Immunologic, histopathologic and PCR gene detection techniques can also lead to diagnosis, but none of these alternatives provide a diagnosis in all the cases [8].

Bartonella is the only genus of bacteria that is capable of promoting cutaneous angioproliferation, as observed in verruga peruana (a skin-blistering stage of Carrion's disease) and in bacillary angiomatosis [7].

In both cases the clinical condition seems to be associated with the immunological state of the host. Verruga peruana installs itself after hemolytic and 
immunosuppressive manifestations, which are called Oroya fever $[12,13]$. Bacillary angiomatosis, whether accompanied or not by liver peliosis, is much more frequent in immunodeficient patients, especially HIVpositive ones [6,14-17].

Besides the possibility of host immunity, other factors may affect the development of infection, such as the virulence of the bacteria, the inoculation route, and the participation of vectors. It is well known that Phlebotomus spp. are Carrion's disease vectors. Body lice and even head lice may transport Bartonella quintana, transmitting trench fever. Ticks have been connected with the transmission of this bacteria in trench fever $[5,6]$. Fleas are important in the transmission of Bartonella henselae among felines, though their role in the transmission of infection to men is still controversial [18]. Spach et al., 1995, reported cases of bacteremia by bartonellas, half of them associated with scabies [19]. The participation of the Sarcoptes scabie as vector of the remaining human bartonelloses is unknown.

\section{What We Know (Table 1)}

In 1885, Carrion's disease was named after a Peruvian medical student called Daniel Alcidés Carrión, who tried to show that two endemic diseases in his country, Oroya fever and verruga peruana, were stages of the same infection. He inoculated himself with material obtained from a patient with verruga peruana and died with the clinical manifestations of Oroya fever [12].

Carrion's disease is caused by $B$. bacilliformis; the vector is an arthropod of limited flying range, Lutzomya verrucarum. In endemic areas, $60 \%$ of the population is seropositive to the bacteria and $10 \%$ to $15 \%$ are asymptomatic carriers. The latter are the disease reservoirs $[5,12]$.

Oroya feveroccurs in non-immune patients, as an acute hemolytic stage, three weeks after exposure. It is immunosuppressive and the high mortality rates, still registered, are due to acute anemia, opportunist infections, or the reactivation of concomitant infections. Treatment is made with tetracycline or chloramphenicol. The response is quick and this stage is interrupted [5-7,20].
At the next stage, which lasts from two to eight weeks, after apparent recuperation from Oroya fever, the patient can present superficial or subcutaneous angiomatous lesions. These may persist for months or years. The severity of the eruptions is variable and seems to be independent of previous antibiotic treatment. Lesions are indistinguishable from those observed in bacillary angiomatosis [21,22].

Trench fever was recognized as a clinical entity in the First World War epidemic, in 1915. Rocha-Lima, a Brazilian researcher, studied the bacteria in the gut of the body lice. He demonstrated that these arthropods were vectors of Bartonella quintana infection. The bacteria were found in lice saliva and feces, and infected humans when the skin was broken $[5,17]$.

Endemic or epidemic infection seems to be predominantly associated with bad personal and sanitary hygiene conditions. More recently, studies of the homeless have created terms like "modern-day trench fever" $[4,17]$.

After an incubation period of approximately three weeks, feverish episodes normally have afive-day duration. It is also called Quintanafever, may have variable intensity, and clinical paroxysmal exacerbations three to five times per year. Studies with volunteers have demonstrated susceptibility to re-infection. The response to treatment is described as being dramatic within one or two days after the initiation of tetracycline or chloramphenicol administration $[5,7,17]$. Some of the treated patients present recrudescence and the subsequent effect that these drugs have on the agent is unknown [23].

Cat-scratch disease's clinical manifestations were first published in 1950, even though it was recognized before. The intradermal test of Rose and Hanger was used for the first time for diagnosis in 1946 [24,25]. Today it is known that the Bartonella henselae is responsible for the great majority of cases of this disease [4]. Bartonella clarridgeiae and B. quintana have also been associated with cat-scratch disease in case reports [26,27]. This disease, which has been reported throughout most of the world, is the main cause of benign adenopathy in children and young adults [2].

The involvement of the domestic cat in this zoonosis is one of the diagnostic criteria, although a small percentage of patients deny contact with these animals [25]. 
Table 1. Bartonella species, year of description, natural hosts and main human disease

\begin{tabular}{lcll}
\hline Bartonella spp. & Year of description & Natural hosts & Main human diseases \\
\hline B. bacilliformis & 1907 & Human & CD \\
B. tal pae & 1911 & Mole & \\
B. quintana & 1917 & Human & TF, CSD, BA, CA, B, E, S \\
B. peromysci & 1942 & Dear, mouse & \\
B. vinsonni subspecie vinsonni & 1946 & Vole & \\
B. henselae & 1992 & Cat & CSD, BA, CA, B, E, S \\
B. elizabethae & 1993 & Rat & E, N \\
B. grahamii & 1995 & Mouse, vole & N \\
B. taylorii & 1995 & Mouse, vole & \\
B. doshiae & 1995 & Vole & \\
B. vinsonni subspecie berkhoffi & 1996 & Dog & E \\
B. clarridgeiae & 1996 & Cat & CSD \\
B. tribocorum & 1998 & Rat & \\
B. alsatica & 1999 & Rabbit & \\
B. koehlerae & 1999 & Cat & B \\
B. vinsonni subspecie arupensis & 1999 & Mouse & \\
B. birtlesi & 2000 & Mouse & \\
B. weissii & 2001 & Cattle & \\
\hline CD: Carrión disease, TF: trench fever, CSD: cat scratch disease, BA: bacillary angiomatosis, CA: chronic adenopathy, B: bacteremia, \\
E: endocarditis, S: septicemia. & & &
\end{tabular}

Seroprevalence of $B$. henselae among cats is high. In a Brazilian study, it was found in $46 \%$ of the cats [28].

In its typical form, cat-scratch disease is benign, subacute, self-limiting, and has a higher rate in children. From three to five days post-cutaneous trauma, primary lesions appear as erythematous papules that regress in a few days, remaining as macules for two to three months. The unilateral adenopathy, usually with just one lymph node enlarged, is considered to be the sign of the disease; it lasts for two to three months. Suppuration occurs in $10 \%$ of the cases. Fever, when it occurs, is low $[6,25,29]$.

The Parinaud oculo-glandular syndrome is found among the atypical manifestations of the disease [30,31]. Encephalitis is the most frequent neurological manifestation [25].

Another diagnostic criterion is the characteristic histological pattern. There is a granulomatous infiltrate with a central necrotic area, surrounded by lymphocytes, histiocytes, and neutrophils. Delicate and pleomorphic bacilli may be seen with the Warthin-Starry stain, within the area of necrosis; they are rare in the mature granulomas [16]. The advantage of treatment is doubtful, especially in typical cases [25,32].
In 1983, the first case of bacillary angiomatosis was described in an immunodeficient Aids patient who had a $\mathrm{CD}_{4}$ count of 40 cells $/ \mathrm{mm}^{3}$ [33]. This disease may be caused by Bartonella henselae and Bartonella quintana; it occurs predominantly in adult men with Aids, especially those with very low $\mathrm{CD}_{4}[14,15,34,35]$.

Clinical manifestations vary, but vascular proliferation lesions are representative. The most common lesions are cutaneous, however practically the whole organism may be affected. Papular and papulo-tumoral angiomatous lesions or nodules may be observed. Indurate and hyperpigmented plaques are less frequent, but may be indistinguishable from Kaposi's sarcoma [6,14,16,17,22,36,37]. Mohle-Boetani et al., 1996, in a case-control study, found $45 \%$ of the patients to have bacillary angiomatous cutaneous lesions [38].

Immunocompetent patients may present disseminated visceral lesions. Hepatis or splenic bacillary peliosis, a form of angiomatosis with capillary dilatation forming cavernous spaces full of blood, has been associated only with Bartonella henselae [7,17,37,39]. The role of the domestic cat is not always demonstrated, though it was found to be significantly correlated with disease in an 
epidemiological study made by Tappero et al., 1993 [15]. Potentially fatal in its course, diagnosis may be established clinically, but should be confirmed by culture, histologic, serologic, or gene detection techniques [8].

In most cases, experienced pathologists can make a diagnosis with hematoxylin and eosin staining $[37,40]$. There is vessel proliferation with lobular disposition. The central ones are more differentiated and the peripheral ones less mature. The lumens sometimes go unnoticed. Multiple mitoses may occur and atypical cells may be found near the necrosis areas. The presence of leukocytes and leukocytoclasis in the interstitial lobule of the nonulcerated lesions is a diagnostic clue. They are found around clumps of bacteria, and are fibrin-like when they are stained with hematoxylin and eosin. Warthin-Starry staining may facilitate demonstration of the agent. Electron microscopy allows for individualization of the trilaminarwalled agents. Immune histochemistry staining permits differentiation between Bartonella henselae and Bartonella quintana [9,41-45].

Erythromycin and doxycycline are the most commonly used drugs. However, they must be taken for two to four months in order to reduce the risk of a relapse $[17,46]$.

\section{What We Do Not Know}

Even without a precise classification, these bacteria have a lot to teach us: they live with cats, rats, mice, rabbits, and possibly with man. This is evidenced by the presence of $10 \%$ to $15 \%$ asymptomatic carriers in the human population of endemic areas of Carrion's disease, and during trench fever epidemics $[5,12]$.

Another data that indicate asymptomatic infection is the finding that $40 \%$ of the people infested with infected lice during trench fever epidemics remained healthy. Also positive Bartonella bacilliformis serology has been found in $60 \%$ of the inhabitants of endemic areas of Carrion's disease [5,12]. Two to six percent of the normal population in the United States of America were found to have positive serological exams for $B$. henselae. In Switzerland it was found to be $48 \%$ and in Germany, $19 \%$ [47-49].

Carithers, 1985, reported a positive skin test reaction in $18 \%$ of family members that had come into frequent contact with cat-scratch disease patients. The great majority of them expressed a liking for cats [25]. Considering that $B$. bacilliformis and $B$. henselae may be found in erythrocytes $[13,50]$, studies must be made on the risk of transfusional infection fromasymptomatic donors. This infection may not manifest itself in the days subsequent to transfusion, and may have diverse clinical expressions.

The expression of a possible infection may depend on the immunological state of the host. Verruga peruana seems to occur in patients with partial immunity to $B$. bacilliformis infection [22]. The concomitance of lesions with clinical-pathological characteristics of catscratch disease and bacillary angiomatosis, reported after the use of corticosteroids, and as one single agent is demonstrated, indicates that these are polar expressions of the same infection [51].

Cat-scratch disease is more frequent in children, while bacillary angiomatosis is more frequent in adults [22,25]. Is this disease due to the re-exposition of the organism to a bacterium of the same genus? Or are they clinical manifestations of infection by different strains of Bartonella henselae, which, as clinically suggested by Anderson and Neuman, 1997, may have different virulences? [4].

The main route of inoculation seems to be the skin, but the importance of this factor in the development of infection, is still unknown [8]. There is also a predominance of angiomatous skin lesions [38]. The high concentration of carbon monoxide in skin tissue could be one of the variables involved in the tropism [52].

The role of the different vectors involved in human bartonelloses in determining clinical expression is ignored [8]. In the Rock Mountain fever group there is "activation" of the agent in the vector, and human infection does not occur without this passage process [53]. Whether it is necessary for bartonellas to become more virulent is also unknown.

In one of the authors' case studies, a histological skin section showed an intimate relationship between Sarcoptes scabei and an angiomatous lesion, rich in bacilli. If this was casual, since the patient presented Norwegian scabies, or if this ectoparasite is also a vector of bartonellas, is unclear. Spach et al., 1995, reported an association of scabies with half of the patients with B. quintana bacteremia [19]. We suggest an association of scabies with bacillary angiomatosis. 
A good portion of our inquiries might be clarified with more appropriate diagnostic methods. The sensitivities of the direct exam, histopathologic, culture, serologic, and genic detection techniques are still unsatisfactory [8]. It is necessary to associate each other in order to improve the accuracy of diagnosis.

Also, the precise mechanisms of antibiotic action in bartonella infection remain unknown. Even though the initial response to antibiotic therapy is described as dramatic in Oroya fever and bacillary angiomatosis, it seems to be negligible in most of cases of typical catscratch disease. Antibiotics do not seem to stop the evolution of Oroya fever to verruga peruana, nor do they impede recrudescence in patients with trench fever and bacillary angiomatosis [8].

From all this we can observe that the more we study about this bacterial genus, the less we seem toknow about it.

\section{References}

1. Spach D.H., Koehler J.E. Bartonella-associated infections. Emerg Infect Dis 1998;12:137-55.

2. Dehio C., Sander A.Bartonella as emerging pathogens. Trends Microbiol 1999; 7:226-8.

3. Brenner D.J., O'Connor S.P., Winkler H.H., Steigerwalt A.G. Proposals to unify the genera Bartonella and Rochalimaea, with descriptions of Bartonella quintana comb. nov., Bartonella vinsonii comb. nov., Bartonella henselae comb. nov., and Bartonella elizabethae comb. nov., and to remove the family Bartonellaceae from the order Rickettsiales. Int J Syst Bacteriol 1993;43:77-86.

4. Anderson B.E., Neuman M.A. Bartonella spp. as emerging human pathogens. Clin Microbiol Rev 1997;10:203-19.

5. Bass J.W., Vincent J.M., Person D.A. The expanding spectrum of Bartonella infections: I. Bartonellosis and trench fever. Pediatr Infect Dis J 1997;16:2-10.

6. Bass J.W., Vincent J.M., Person D.A. The expanding spectrum of Bartonella infections: II. Cat-Scratch disease. Pediatr Infect Dis J 1997;16:163-79.

7. Raoult D. Infections humaines à Bartonella. Presse Med 1999;28:429-34.

8. Velho P.E.N.F. Estudo das bartoneloses humanas e da Bartonella henselae: infecção experimental, microbiologia e microscopia de luz e eletrônica de transmissão. Campinas, 2001. [Tese- Doutorado Faculdade de Ciências Médicas da Universidade Estadual de Campinas].
9. Cockerell C.J., Whitlow M.A., Webster G.F., FriedmanKien A.E. Epithelioid angiomatosis: a distinct vascular disorder in patients with the acquired immunodeficiency or aids-related complex. Lancet 1987;i:654-6.

10. Birtles R.J., Harrison T.G., Saunders N.A., Molyneux D.H. Proposals to unify the genera Grahamella and Bartonella, with descriptions of Bartonella talpae comb. nov., Bartonella peromysci comb. nov., and three new species, Bartonella grahamii sp. nov., Bartonella taylorii sp. nov., and Bartonella doshiae sp. nov. Int J Syst Bacteriol 1995;45:1-8.

11. Daly J.S., Worthington M.G., Brenner D.J., et al. Rochalimae elizabethae sp. nov. isolated from a patient with endocarditis. J Clin Microbiol 1993;31:872-81.

12. Garcia-Caceres U., Garcia F.U. Bartonellosis: an immunodepressive disease and the life of Daniel Alcides Carrión. Am J Clin Pathol 1991;95(suppl.1):58-66.

13. Garcia F.U., Wojta J., Broadley K.N., et al. Bartonella bacilliformis stimulates endothelial cells in vitro and is angiogenic in vivo. Am J Pathol 1990;136:1125-34.

14. Spach D.H., Panther L.A., Thorning D.R., et al. Intracerebral bacillary angiomatosis in a patient infected with human immunodeficiency virus. Ann Intern Med 1992;116:740-2.

15. Tappero J.W., Mohle-Boetani J., Koehler J.E., et al. The epidemiology of bacillary angiomatosis and bacillary peliosis. J Am Med Assoc 1993;269:770-5.

16. Loutit J.S. Bartonella infections. Cur Clin Top Infec Dis 1997;17:269-90.

17. Maurin M., Raoult D. Bartonella (Rochalimaea) quintana infections. Clin Microbiol Rev 1996;9:273-92.

18. Chomel B.B., Kasten R.W., Floyd-Hawkin K., et al. Experimental transmition of Bartonella henselae by the cat flea. J Clin Microbiol 1996;34:1952-6.

19. Spach D.H., Kanter A.S., Dougherty M.J., et al. Bartonella (Rochalimae) quintana bacteremia in inner city patients with chronic alcoholism. N Engl J Med 1995;332:424-8.

20. Mitchell S.J., Minnick M.F. Characterization of a two-gene locus from Bartonella bacilliformis associated with the ability to invade human erythrocytes. Infect Immun 1995;63:1552-62.

21. Alexander B. Review of bartonellosis in Ecuador and Colombia. Am J Trop Med Hyg 1995;52:354-9.

22. Nosal J.M. Bacillary angiomatosis, cat-scratch disease, and bartonellosis: what's the connection? Int J Dermatol 1997;36:405-11.

23. Brouqui P., La Scola B., Roux V., Raoult D. Chronic Bartonella quintana bacteremia in homeless patients. N Engl J Med 1999;340:184-9.

24. Carithers H.A. Cat-scratch disease: notes on its history. Am J Dis Child 1970; 119:200-3.

25. Carithers H.A. Cat-scratch disease. An overview based on a study of 1,200 patients. Am J Dis Child 1985; $139: 1124-33$. 
26. Kordick D.L., Hilyard E.J., Hadfield T.L., et al. Bartonella clarridgeiae, a newly recognized zoonotic pathogen causing inoculation papules, fever, and lymphadenopathy (cat scratch disease). J Clin Microbiol 1997;35:1813-8.

27. Azevedo Z.M., Higa L.Y., Boechat M.B., Klaplauch F. Catscratch disease caused by Bartonella quintana in an infant: an unusual presentation. Rev Soc Bras Med Trop 2000;33:313-17.

28. Slhessarenko N., Camargo M.C.G.O., D’Auria S.R.N., et al. Soroprevelência de Bartonella henselae em gatos do município de São Paulo. Rev Soc Bras Med Tropic 1996;29:104.

29. Margileth A.M. Cat-scratch disease. Adv Pediatr Infect Dis 1993; 8:1-21.

30. Wear D.J., Malaty R.H., Zimmerman L.E., et al. Cat-scratch disease bacilli in the conjunctiva of patients with Parinaud's oculo-glandular syndrome. Ophthalmol 1985;92:1282-7.

31. Huang M.C., Dreyer E. Parinaud's oculoglandular conjuntivitis and cat-scratch disease. Int Ophthalmol Clin 1996; $36: 29-36$.

32. Bass J.W., Freitas B.C., Freitas A.D., et al. Prospective randomized double blind placebo-evaluation of azithromycin for treatment of cat-scratch disease. Pediatr Infect Dis J 1998; 17:447-52.

33. Stoler M.H., Bonfiglio T.A., Steigbigel R.T., Pereira M. An atypical subcutaneous infection associated with acquired immune deficiency syndrome. Am J Clin Pathol 1983;80:714-8.

34. Regnery R.L., Anderson B.E., Clarridge III J.E., et al. Characterization of a novel Rochalimaea species, $R$. henselae sp. nov., isolated from blood of a febrile, viruspositive. J Clin Microbiol 1992;30:265-74.

35. Koehler J.E., Quinn F.D., Berger T.G., et al. Isolation of Rochalimaea species from cutaneous and osseous lesions of bacillary angiomatosis. N Engl J Med 1992;327:1625-31.

36. Baker J., Ruin-Rodriguez R., Whitfield M., et al. Bacillary angiomatosis: a treatable cause of acute psychiatric symptoms in human immunodeficiency virus infection. J Clin Psychiatry 1995;56:161-6.

37. Cockerell C.J., LeBoit P.E. Bacillary angiomatosis: A newly characterized, pseudoneoplastic, infectious, cutaneous vascular disorder. J Am Acad Dermatol 1990;22:501-12.

38. Mohle-Boetani J.C., Koehler J.E., Berger T.G., et al. Bacillary angiomatosis and bacillary peliosis in patients infected with human immunodeficiency virus: clinical characteristics in a case-control study. Clin Infect Dis 1996; $22: 794-800$.

39. Milam M.W., Balerdi M.J., Toney J.F., et al. Epithelioid angiomatosis secundary to disseminated cat-scratch disease involving bone marrow and skin in a patient with acquired disease syndrome: a case report. Am J Med 1990;88:180-3.
40. LeBoit P.E., Berger T.G., Egbert B.M., et al. Bacillary angiomatosis: the histopathology and differential diagnosis of a pseudoneoplastic infection in patients with human immunodeficiency virus disease. Am J Surg Pathol 1989;13:909-10.

41. Angritt P., Tuur S.M., Macher A.M., et al. Epithelioid angiomatosis in HIV infection: neoplasm or cat-scratch disease? Lancet 1988; 1:996. [Letter]

42. Berger T.G., Tappero J.W., Kaymen A., LeBoit P.E. Bacillary (epithelioid) angiomatosis and concurrent Kaposi's sarcoma in acquired immunodeficiency syndrome. Arch Dermatol 1989; 125:1543-7.

43. Chan J.K.C., Lewin K.J., Lombard C.M., et al. Histopathology of bacillary angiomatosis of limph node. Am J Surg Pathol 1991;15:430-7.

44. Kemper C.A., Lombard C.M., Deresinski S.C., Tompkins L.S.Viceral bacillary angiomatosis: possible manifestations of disseminated cat-scratch disease in the immunocompromised host: a report of two cases. Am J Med 1990;89:216-22.

45. Reed J.A., Brigati D.J., Flynn S.D., McNutt N.S., Slater L.N. Immunocytochemical identification of Rochalimaea henselae in bacillary (epithelioid) angiomatosis parenchymal bacillary peliosis and persistent fever with bacteremia. Am J Surg Pathol 1992; 16:650-7.

46. Koehler J.E. Bartonella-associated infections in HIVinfected patients. Aids Clin Care 1995;7:97-102.

47. Rath P.M., Von Recklinghausen G., Ansorg R. Seroprevalence of immunoglobulin $\mathrm{G}$ antibodies to Bartonella henselae in cat owners. Eur J Clin Microbiol Infect Dis 1997;16:326-7. [Letter]

48. Bergmans A.M.C., Jong C.M.A., Amerongem V., et al. Prevalence of Bartonella species in domestic cats in the Netherlands. J Clin Microbiol 1997;35:2256-61.

49. Comer J.A., Flynn C., Regnery R.L., et al. Antibodies to Bartonella species in inner-city intravenous drug users in Baltimore, Md. Arch Intern Med 1996;156:2491-5.

50. Kordick D., Breitschwerdt E.B. Intraerythrocytic presence of Bartonella henselae. J Clin Microbiol 1995;33:1655-6.

51. Schlossberg D., Morad Y., Krouse T.B., et al. Cultureproved disseminated cat-scratch disease in acquired immunodeficiency syndrome. Arch Intern Med 1989;149:1437-9.

52. Miller A.C., Walker J., Jaworski R., et al. Hookworm folliculitis. Arch Dermatol 1991;127: 547-9.

53. Greene C.E. Rocky Mountain spotted fever. J Am Vet Med Assoc 1987;191:666-71. 